\title{
Diet Composition, Forage Selection, and Potential for Forage Competition Among Elk, Deer, and Livestock on Aspen-Sagebrush Summer Range
}

\author{
Jeffrey L. Beck ${ }^{1}$ and James M. Peek ${ }^{2}$ \\ Authors are ${ }^{1}$ Postdoctoral Wildlife Ecologist, Department of Zoology and Physiology, University of Wyoming, \\ Laramie, WY 82071-3166; and ${ }^{2}$ Professor Emeritus, Department of Fish and Wildlife Resources, University of Idaho, \\ Moscow, ID 83844-1136. At the time of research, lead author was Graduate Research Assistant, \\ Department of Fish and Wildife Resources, University of Idaho, Moscow, ID 83844-1136.
}

\begin{abstract}
We evaluated elk (Cervus elaphus), mule deer (Odocoileus hemionus), cattle (Bos taurus), and domestic sheep (Ovis aries) diet composition, diet overlap, and forage selection on aspen (Populus tremuloides Michaux)-sagebrush (Artemisia spp. L.) summer range in northeastern Nevada to understand potential for forage competition to provide better information for managing these communities. Diets were determined through microhistological fecal analysis from 1998 to 2000, and forage selection was evaluated at feeding sites in aspen and sagebrush communities in 1999 and 2000. Elk spring diets were the most diverse in composition; summer elk diets were dominated by forbs $(59 \%-78 \%)$; deer consumed mostly woody browse $(64 \%-72 \%)$; and cattle and sheep ate mostly graminoids. Lupines (Lupinus spp. L.) constituted $\geq 11 \%$ of elk, deer, and sheep diets in summer. Spurred lupine (Lupinus caudatus Kellogg) was the lupine typically selected in feeding sites and greatest consumption occurred in summer when total alkaloid levels were lowest. Highest diet overlap was between cattle and sheep in $1999(68 \%)$ and lowest between deer and cattle in $2000(3 \%)$. Summer elk and deer diets overlapped moderately $(45 \%-59 \%)$. Diets did not differ between elk in spring with sheep, elk in summer with deer and sheep, or cattle with sheep. Cattle foraged selectively on forbs in aspen communities $(68 \%)$ and on graminoids in sagebrush communities $(88 \%)$, reflecting relative forage availabilities. We detected no differences among elk, cattle, and sheep for forage selection in aspen communities. Electivity indices indicated elk preferred forbs in aspen and sagebrush communities; cattle preferred graminoids in sagebrush; and foraging sheep preferred forbs in aspen. Our results suggest potential for forage competition among ungulates on aspen-sagebrush summer range is highest for forbs in aspen communities. Monitoring productivity and use of key forage species, particularly forbs in aspen communities, should complement management objectives on shared aspen-sagebrush summer range.
\end{abstract}

\section{Resumen}

Las Comunidades de Aspen (Populus tremuloides Michaux) y Sagebrush (Artemisia spp. L.) Son importantes fuentes de forraje par los ungulados que habitan muchos de los pastizales de verano del oeste; sin embargo, la información sobre la competencia potencial por el forraje en estas comunidades es limitada. Con el propósito de entender la competencia potencial por el forraje y suministrar mejor información para el manejo de estas comunidades vegetales evaluamos la composición y similitud de la dieta y la selección de forraje del alce (Cervus elaphus), venado (Odocoileus hemionus), bovinos (Bos taurus) y ovinos (Ovis aries) apacentando un pastizal de verano de aspen-sagebrush del nordeste de Nevada. La dietas se determinaron mediante análisis microhistológico de heces fecales de 1998 al 2000 y en 1999 y 2000 se evaluó la selección de forraje en los sitios de alimentación de las comunidades de aspen y sagebrush. Las dietas del alce en primavera fueron las más diversas en composición, y en verano, su dieta estuvo dominada por hierbas $(59 \%-78 \%)$; el venado consumió principalmente especies leñosas $(64 \%-72 \%)$ y los bovinos y ovinos comieron principalmente gramíneas. Los lupinos (Lupinus spp. L.) constituyeron $\geq 11 \%$ de la dieta de verano del alce, venado y ovinos. El "Spurred lupine" (Lupinus caudatus Kellogg) fue el "Lupino" típicamente seleccionado por los ungulados en los sitios de alimentación y el mayor consumo ocurrió en verano cuando los niveles totales de alcaloides fueron los más bajos. La mayor similitud de la dieta se registró en 1999 entre los bovinos y ovinos (68\%) y el menor entre el venado y los bovinos en el $2000(3 \%)$. En verano, las dietas del alce y el venado se traslaparon moderadamente $(45 \%-59 \%)$. En primavera la dieta del alce y los ovinos no difirió, lo mismo ocurrió en verano con la dieta del alce, el venado y los ovinos y la dieta de los bovinos y ovinos. Los bovinos apacentaron selectivamente las hierbas en las comunidades de aspen (68\%) y en las gramíneas en las comunidades de sagebrush $(88 \%)$, reflejando disponibilidades relativas de forraje. En las comunidades de aspen no detectamos diferencias entre el alce, bovinos y ovinos en la selectividad de forraje. Los índices de selectividad indicaron que el alce prefirió las hierbas en las comunidades de aspen-sagebrush; el ganado prefirió las gramineas en la comunidad de sagebrush

The USDA Humboldt-Toiyabe National Forest, Nevada Division of Wildlife, Rocky Mountain Elk Foundation, Nevada Bighorns Unlimited, Elko Bighorns Unlimited, USDI Bureau of Land Management, National Fish and Wildlife Foundation, Safari Club International, the College of Natural Resources, and the Cooperative Fish and Wildlife Research Unit, University of Idaho, supported our research.

Correspondence: Jeffrey L. Beck, Department of Zoology and Physiology, University of Wyoming, Laramie, WY 82071-3166. Email: jl_beck@yahoo.com

Manuscript received 24 February 2003; manuscript accepted 14 November 2004. 
y los ovinos prefirieron las hierbas cuando apacentaron en las comunidades de Aspen. Nuestros resultados sugieren que la competencia potencial por el forraje entre los ungulados en los pastizales de verano de aspen-sagebrush es mayor para las hierbas en las comunidades de aspen. El monitoreo de la productividad y el uso de las especies forrajeras clave, particularmente en las comunidades de aspen, debe ser un objetivo de manejo obligado en los pastizales de verano compartidos de aspensagebrush.

Key Words: alkaloids, cattle, diet overlap, domestic sheep, feeding sites, Nevada, spurred lupine

\section{INTRODUCTION}

Morphophysiological characteristics such as salivary glands, body and mouth sizes, type of digestive system (cecal or ruminant), and rumino-reticular volume to body weight ratios predispose ungulates to selectively harvest forages (Hanley 1982; Hanley and Hanley 1982; Hofmann 1989). Advanced forestomach development in cattle (Bos taurus) and domestic sheep (Ovis aries) facilitates efficient digestion of graminoids that are high in cell wall, while smaller forestomachs and large salivary glands in deer facilitate nutrient assimilation from heavily defended, nutritious, and highly digestible forbs and woody browse high in cell solubles (Hofmann 1989). Elk (Cervus elaphus) are intermediate in digestive capabilities, displaying great variability in seasonal forage selection. Elk forage ranges from highly digestible forbs, woody stems, and young grasses to less digestible mature grasses and sedges (Cook 2002). However, ungulate diet selection is largely influenced by forage availabilities in spite of anatomical adaptations that facilitate selection for specific diets (e.g., Tueller and Monroe 1975; Ralphs and Pfister 1992; Kie and Boroski 1996).

Dietary patterns and overlap indices for sympatric ungulates provide insights into potential interspecific competition, population nutritional needs, and forage allocation and can be used to identify key indicator plants of rangeland health. Competition for food has been studied more than other aspects of competitive interactions among large herbivores (Miller 2002) even though the relationship between interspecific competition and niche overlap is ambiguous (Abrams 1980). However, the magnitude of diet overlap should indicate potential competition at high population densities. Conditions that must exist for forage competition among ungulates include 1) species use the same area, 2) forage plants must be in short supply or are impaired in production due to combined use, and 3) species use the same forage plants (Cole 1958; Holechek 1980). The common use of limited resources by two or more species can result in exploitative competition, or reduced performance in one species due to competition for limited resources (Wisdom and Thomas 1996). Evaluating forage selection for sympatric ungulates in important foraging communities is thus critical to deduce potential for competition.

We compare diets and forage selection of a recently reintroduced elk population in northeastern Nevada with other ungulates commonly found on aspen (Populus tremuloides Michaux)-sagebrush (Artemisia spp. L.) summer range. In our study area, aspen communities occupied mesic sites among a sagebrush complex consisting of mountain big sagebrush (Artemisia tridentata ssp. vaseyana [Rydb.] Beetle) and low sagebrush (Artemisia arbuscula Nutt.) interspersed with herbaceous meadows. Aspen and sagebrush-herb communities collectively covered $67 \%$ of summer range and contributed the most to elk nutritional carrying-capacity estimates adjusted to reflect predicted use of community types (Beck 2003). Elk shared summer range with mule deer (Odocoileus hemionus), cattle, and domestic sheep, which also relied heavily on aspen and sagebrush for forage during summers in our study area.

Aspen and mountain big sagebrush communities occur together in mesic mountain zones across the western United States and are known for their high diversity and productivity of forbs, graminoids, and shrubs (Mueggler 1988; Tisdale 1994). Where found, these communities comprise important summer forage resources to livestock and wildlife (DeByle 1985; Tisdale 1994). Forage competition by ungulates in these communities could lead to changes in community structure and concomitant declines in forage production and secondary production (i.e., gain) among competing ungulates (Hobbs et al. 1996a, 1996b).

We evaluate the potential for forage competition among elk, mule deer, cattle, and domestic sheep on shared aspensagebrush summer range at the forage category (forbs, graminoids, and woody browse) level, in plant communities, and under environmental conditions spanning 3 years. Previous studies evaluating diets of sympatric ungulates have provided insights on conditions that influence diet overlap. For example, Mower and Smith (1989) found that elk and mule deer diets overlapped $71 \%$ on limited winter range in central Utah where shrubs comprised the largest portion of elk and deer diets. Seasonal food habits of cattle, domestic sheep, elk, pronghorn (Antilocapra americana), and wild horses were investigated on rangeland dominated by rabbitbrush (Chrysothamnus spp. Nutt.), sagebrush, and saltbush (Atriplex spp. L.) in southwestern Wyoming (Olsen and Hansen 1977). Here, there was much variation in diet overlap among herbivores and seasons, suggesting ungulates selected seasonal diets independently (Olsen and Hansen 1977). Information on forage selection was not available for these 2 studies and is not available for many other earlier studies, thus precluding quantification of potential forage competition. In contrast, tame, free-ranging elk selected more forage species and older and coarser plant parts than tame mule deer on aspen and lodgepole pine (Pinus contorta Dougl. ex Loud.) summer ranges in Utah (Collins and Urness 1983). The feeding niche for elk overlapped and was wider than that of mule deer, leading these researchers to conclude that there was considerable potential for exploitative competition in aspen and lodgepole pine communities favoring elk over mule deer (Collins and Urness 1983). Objectives of our research were to 1) investigate elk, mule deer, cattle, and domestic sheep diet composition on shared aspen-sagebrush summer range over 3 years, 2) evaluate elk, cattle, and domestic sheep forage selection at feeding sites in aspen and sagebrush communities over 2 years, 3) describe food-niche overlap among this suite of ungulates, 4) evaluate alkaloid content in spurred lupine (Lupinus caudatus Kellogg) to clarify 
relationships between seasonal alkaloid content and consumption of lupine by ungulates, and 5) identify potentially competitive foraging scenarios for these herbivores on shared, aspen-sagebrush summer range.

\section{MATERIALS AND METHODS}

\section{Study Area}

Summer range (2 $135-3287 \mathrm{~m})$ covers about $48 \%$ of our 166500 ha study area (lat $41^{\circ} 30^{\prime}$ to lat $42^{\circ} 00^{\prime} \mathrm{N}$, long $115^{\circ} 00^{\prime}$ to long $\left.115^{\circ} 30^{\prime} \mathrm{W}\right)$ in the Jarbidge Mountains of northeastern Nevada. The Humboldt-Toiyabe National Forest comprises $92 \%$, Bureau of Land Management $5 \%$, and private lands 3\% of the summer range. The northern slope of the Jarbidge Mountains drains into the Snake River, while southern watersheds feed into the Great Basin (USDA Forest Service 1981). Moisture arrives mainly as snow. The 1 April snow-water equivalents at Draw Creek $(2300 \mathrm{~m})$ and Pole Creek Ranger Station (2 $540 \mathrm{~m}$ ) weather stations were $126 \%, 88 \%$, and $104 \%$ and 94\%, 91\%, and 90\%, of 30-year (1971-2000) averages (Draw Creek, $297 \mathrm{~mm}$; Pole Creek, $523 \mathrm{~mm}$ ) in 1998, 1999, and 2000 , respectively. Mean monthly temperatures $\left({ }^{\circ} \mathrm{C}\right)$ averaged from June through October 1998, 1999, and 2000 were 12, 11, and 14 at Draw Creek $\left(1991-2000 \bar{x}=12^{\circ} \mathrm{C}\right)$, and 10, 10, and 11 at Pole Creek $\left(1991-2000 \bar{x}=10^{\circ} \mathrm{C}\right)$. June through October 1998, 1999, and 2000 cumulative precipitation $(\mathrm{mm})$ was 135 , 104 , and 41 at Draw Creek $(1985-2000 \bar{x}=100)$ and 229, 101 , and 51 at Pole Creek Ranger Station (1985-2000 $\bar{x}=138$ ).

Summer range vegetation was composed of a sagebrushherb complex that formed a matrix between woody communities, including aspen, curlleaf mountain mahogany (Cercocarpus ledifolius Nutt.), snowbrush ceanothus (Ceanothus velutinus Dougl. ex Hook.), and conifer including subalpine fir (Abies lasiocarpa [Hook.] Nutt.), and limber (Pinus flexilis James) and whitebark pines (Pinus albicaulis Engelm.). Lewis (1975) described herbaceous species composing each community. Plant nomenclature throughout our paper follows USDA Natural Resources Conservation Service (2004).

Elk were reintroduced into the Jarbidge Mountains from 1990 to 1995 (Nevada Division of Wildlife 1997) and a population of about 300 (summer range density $=0.4 \mathrm{~km}^{-2}$ ) was maintained by antlerless harvest from 1996 through 2000 (Beck 2003). Management objectives call for elk to increase to $1000 \pm 100$ by 2010 , when objectives will be reevaluated (Nevada Division of Wildlife 2000). Mule deer densities averaged $7.9 \mathrm{~km}^{-2}$ from 1998 to 2000 across the 166500 ha study area (L. Gilberston, Nevada Department of Wildlife, personal communication, 2003). A small pronghorn population inhabited sagebrush benches in the northern portion of the study area.

From 1998 through 2000, livestock grazed 11 domestic sheep, 27 cattle, and 1 sheep and cattle common use summer and early fall grazing allotments. We evaluated sheep diets and forage selection in allotments stocked with ewes and lambs: Elk Mountain, stocked at an average rate of 0.34 animal unit months (AUM) $\cdot \mathrm{ha}^{-1}$; and Raker Creek, stocked at an average rate of $0.25 \mathrm{AUM} \cdot \mathrm{ha}^{-1}$. Cattle diets and forage selection were evaluated in allotments stocked with cow/calf pairs: Black Spring/Caudle Creek, stocked at an average rate of 0.79
AUM $\cdot \mathrm{ha}^{-1}$; and Pole Creek, stocked at an average rate of $0.55 \mathrm{AUM} \cdot \mathrm{ha}^{-1}$.

\section{Animal Locations}

Ten cow elk were captured in 1998 and 7 cows in 2000 on winter range with netguns shot from helicopters to facilitate attachment of VHF radio collars (Telemetry-Electronics Consultants, Inc., Mesa, AZ). One cow collared in 1998 summered outside the study area and 5 collared cows were harvested during hunting seasons in 1998 and 1999, limiting the number of collared animals to 7-12 from 1998 to 2000. Radiomarked cows provided locations of elk groups composed primarily of cows, calves, and yearling bulls. Nineteen fixed-wing flights to locate all elk groups accompanying collared cows were conducted during morning hours 1-4 weeks apart in summers 1998-2000 by a Nevada Division of Wildlife biologist. Universal Transverse Mercator coordinates for elk locations were provided to our field crew to facilitate locating elk on the ground. On average, ground counts of elk groups located with radiocollared cows represented $56 \% \pm 10 \%$ of combined adult cow and yearling bull estimates from 1998 to 2000 (Beck 2003).

Samples from adult elk in groups consisting of cows, calves, and yearling bulls were collected in summer to compare to those of female cattle and sheep, which represented the bulk of livestock sharing summer range. Starting at random from either the left or right side of each elk group, we counted and numbered all animals and then used an integer from a random digits table to randomly select one individual elk in each group to represent group locations. Feeding sites were later established where these individual animals were located and fresh fecal samples were collected nearest these locations. In addition, feces and feeding sites were sampled at 4 locations in 1999 from elk groups accompanying 1 collared cow elk that summered in an adjacent area.

We located cattle and sheep groups in grazing allotments through frequent consultations with herders on the whereabouts of livestock. Searches were rotated between allotments to locate livestock groups during sampling periods because livestock were regularly herded among units in each allotment and herders managed sheep in single, large bands in sheep allotments. Starting at random from either the left or right side of each group of cattle or sheep, we counted and numbered all animals and then used an integer from a random digits table to randomly select one individual in each group to represent sampling locations.

We collected elk, cattle, and domestic sheep fecal samples and evaluated feeding sites from locations where we randomly located animal groups. Where possible, we randomly selected an individual animal to provide a sampling location in aspen and a separate individual animal to provide a sampling location in sagebrush when animal groups were distributed between adjacent or nearby communities (Irwin and Peek 1983). Direct observations were necessary because elk, mule deer, and pronghorn were sympatric with each other and with cattle and domestic sheep in grazing allotments. Because we did not have any radiomarked deer to provide locations, we searched areas frequented by mule deer in the northern portion of the study area to collect fresh fecal samples. 


\section{Fecal Collections}

Elk spring diet samples were collected from late May through 9 July 1998-2000 before summer livestock grazing. Summer fecal samples were collected at 1-3-week intervals from 10 July until mid-September 1998-2000, when antlerless elk hunting seasons began. Samples were primarily collected in aspen and sagebrush communities and were collected from single defecations within 1 week of locating individuals in groups. Feces were only collected from adults (based on relative size) to remove bias associated with milk ingested by juveniles. Spring elk pellets represented female and male groups. Pellets were collected from 2 separate defecations in those instances when we randomly located 2 individual elk in groups scattered across aspen and sagebrush communities (Irwin and Peek 1983). Each elk collection consisted of at least 12 individual pellets from single elk fecal deposits.

We collected 3-5 pellet groups per sheep group to represent dietary diversity inherent within bands. One sample was collected from a single fresh cattle pat at each group location. Elk, cattle, and sheep fecal samples were collected within 1 week of group locations to ensure freshness. Freshness of deer pellets was based on color and consistency.

Fresh feces were salted $(\mathrm{NaCl})$, oven-dried at $90^{\circ} \mathrm{C}-100^{\circ} \mathrm{C}$ for at least 1 hour, and placed in a closed box containing a breathable canister of naphthalene to prohibit fungal and insect infestations (Litvaitis et al. 1994). Four grams from each cattle pat, $5 \mathrm{~g}$ from each individual summer elk collection, and 6 pellets, or equivalent fecal matter, from each individual spring elk, mule deer, and sheep collection were combined to form composite diet samples for each ungulate species by year. Jenks et al. (1989) showed that composite fecal samples can provide results similar to individual samples while reducing costs and improving sampling efficiency compared with individual sample analysis. In our study, compositing was more cost effective than individual sample analysis; however, this approach resulted in loss of our ability to evaluate variation among individual animal diets within sampling periods. We reasoned that composite samples would provide an evaluation of proportionate diet selection for each ungulate species during seasons while providing the opportunity to evaluate variability in diets across 3 years.

\section{Microhistological Analysis}

Composite fecal samples were submitted for microhistological analysis to the Wildlife Habitat and Nutrition Laboratory, Washington State University (Pullman, WA). Lists of potential forage species and voucher specimens collected throughout the study area were provided to lab workers to aid in identification of plant fragments in fecal samples. Diets were analyzed as percent cover (Korfhage 1974; Davitt 1979) of plant fragments by species or genera at $\times 100$ magnification of 25 randomly placed microscope views on each of 8 slides. Larger magnification $(\times 200$ 450) was used to aid in identification of discernable plant fragments (Holechek and Valdez 1985). Percent diet composition was calculated by dividing cover of each plant species or genera by total cover observed for all species and multiplying by 100 .

We conducted in vitro forage digestions to provide correction factors to account for differential forage digestibility (Pulliam and Nelson 1979; Smitman 1980). Separate in vitro digestions were conducted for each ungulate species, based on the proportional amount of each forage category (forbs, graminoids, and woody browse) by weight in each seasonal diet. Plant species combined in forage category digestibility trials are listed in Table 1 and were obtained in late June and early August each year (Beck 2003). Late June samples were digested to provide correction factors for spring elk diets and early August forage samples were digested to provide correction factors for summer diets. Rumen fluid was obtained from fistulated beef cattle fed diets of one-third alfalfa (Medicago sativa L.) and two-thirds grass hays. Epidermal and cuticular fragments in the in vitro residue were analyzed for relative cover with 100 views (25 views on 4 slides) as outlined above. Correction factors (CF) for each forage category $i$ were calculated as: $C F_{i}=\left(C_{r v} \times D_{i k}\right) \cdot\left(D_{r k} \times C_{i v}\right)^{-1}$, where $C_{r v}$ is the total cover value of the reference species $r$ in the in vitro digestion $(v)$ residue. $D_{i k}$ is the percent of species $i$ in the known diet $(k) . D_{r}$ is the percent of reference species $r$ in the known diet mixture and $C_{i v}$ is the total cover for forage category $i$ in the in vitro residue (Pulliam and Nelson 1979; Smitman 1980). Broomcorn millet (Panicum miliaceum L.) seed mixed at a rate of $10 \%$ of each forage mixture served as the reference species in forage digestions. Correction factors are $>1$ when dietary compositions are underestimated and $<1$ when dietary composition of plants are overestimated. Final percentage dietary composition thus represented the product of forage category correction factors and the original dietary percentage for each species divided by the sum of this product for all species (Pulliam and Nelson 1979; Smitman 1980).

\section{Dietary Statistical Analyses}

We transformed dietary proportions to account for the unit sum constraint (i.e., data sum to 1) inherent in compositional data. Forbs, graminoids, and woody browse in each diet were transformed into 2 dependent variables by relating natural $\log$ ratios of proportions of forbs to browse ( $\ln [$ forbs/browse]) and proportions of graminoids to browse (ln[graminoids/ browse]) in each diet. Natural log ratio transformations create new variables that are linearly independent from each other and are commonly used to analyze compositional data (Aitchison 1986; Aebischer et al. 1993). In addition, this transformation removed skewness and provided symmetry to diet-ratio distributions. We designated browse as the denominator in these ratios because browse formed the smallest portion of each diet, thus facilitating a better understanding of the relative contribution of forbs and graminoids to each diet. Zero values were assigned a value of 0.001 to avoid computational problems when dividing with zeroes. Natural log ratios were assessed for assumptions of multivariate analysis of variance (MANOVA), including multivariate normality and covariance homogeneity. Statistical procedures were conducted with Statistical Analysis System software (SAS; SAS Institute 2001). Statistical significance was set at $\alpha=0.05$.

We used MANOVA (PROC GLM; SAS Institute 2001) to evaluate the effect of year and species on natural log of dietary forage ratios. It was impossible to directly assess the interaction of year and species due to the lack of replication (i.e., only 1 diet $\times$ species $\times$ year), so we conducted Tukey's 1-degree-offreedom tests on both dependent variables to fit an additive 
Table 1. Elk, mule deer, cattle, and domestic sheep diet composition (\%) for 12 common forage species, Jarbidge Mountains, Nevada, 19982000. Botanical composition of diets evaluated through microhistological fecal analysis.

\begin{tabular}{|c|c|c|c|c|c|c|c|c|c|c|c|c|c|c|c|}
\hline \multirow[b]{2}{*}{ Plant species } & \multicolumn{3}{|c|}{ Elk, spring } & \multicolumn{3}{|c|}{ Elk, summer } & \multicolumn{3}{|c|}{ Mule deer } & \multicolumn{3}{|c|}{ Cattle } & \multicolumn{3}{|c|}{ Sheep } \\
\hline & 98 & 99 & 00 & 98 & 99 & 00 & 98 & 99 & 00 & 98 & 99 & 00 & 98 & 99 & 00 \\
\hline \multicolumn{16}{|l|}{ Forbs } \\
\hline Balsamorhiza sagittata (Pursh) Nutt. & 3 & $<1$ & 7 & 4 & 1 & $<1$ & 3 & 1 & 4 & 0 & 0 & 0 & 0 & 0 & 0 \\
\hline Lupinus spp. L. & 3 & 6 & 17 & 41 & 29 & 38 & 48 & 32 & 44 & $<1$ & 2 & $<1$ & 11 & 14 & 47 \\
\hline \multicolumn{16}{|l|}{ Grasses } \\
\hline Achnatherum spp. Beauv. & 6 & 2 & 2 & 1 & 3 & 6 & 0 & 1 & $<1$ & 18 & 13 & 16 & 15 & 12 & 7 \\
\hline Bromus marginatus Nees ex Steud. & 9 & 7 & 2 & 1 & 1 & 3 & $<1$ & $<1$ & $<1$ & 5 & 5 & 3 & 4 & 3 & 1 \\
\hline Festuca idahoensis Elmer & 4 & 2 & 1 & 0 & 7 & 5 & 1 & 0 & $<1$ & 5 & 4 & 3 & 6 & 4 & 2 \\
\hline Poa pratensis $\mathrm{L}$. & 0 & 0 & 3 & 2 & 0 & 6 & 0 & 0 & 1 & 3 & 9 & 20 & 6 & 8 & 12 \\
\hline Poa secunda J. Presl & 10 & 7 & 0 & 0 & 6 & 0 & 1 & 1 & 0 & 7 & 11 & 13 & 13 & 16 & 6 \\
\hline Pseudoroegneria spicata (Pursh) A. Löve & 7 & 8 & 2 & 1 & 5 & 5 & 2 & 0 & 0 & 14 & 20 & 27 & 15 & 12 & 12 \\
\hline \multicolumn{16}{|l|}{ Woody browse } \\
\hline Ceanothus velutinus Dougl. ex Hook. & 6 & 22 & 6 & 1 & 4 & 0 & 4 & 12 & 9 & 0 & 0 & 0 & 0 & 1 & 0 \\
\hline Cercocarpus ledifolius Nutt. & 2 & 7 & 5 & 2 & 0 & 0 & 8 & $<1$ & 1 & 0 & 0 & 0 & 0 & 0 & 0 \\
\hline Populus tremuloides Michaux & $<1$ & 0 & 0 & 0 & 0 & 0 & 0 & 0 & 0 & 0 & 0 & 0 & 0 & 0 & 0 \\
\hline Symphoricarpos oreophilus Gray & 1 & 2 & 0 & 0 & 0 & 0 & 0 & 0 & 0 & 0 & 0 & 0 & 0 & 0 & 0 \\
\hline Total $(\%)^{1}$ & 52 & 64 & 45 & 53 & 56 & 64 & 68 & 48 & 61 & 53 & 64 & 83 & 70 & 70 & 87 \\
\hline Richness $^{2}$ & 32 & 32 & 38 & 29 & 31 & 29 & 26 & 28 & 29 & 21 & 26 & 16 & 25 & 30 & 17 \\
\hline Samples $(n)^{3}$ & 25 & 11 & 15 & 22 & 20 & 23 & 15 & 27 & 32 & 26 & 29 & 37 & 31 & 64 & 85 \\
\hline
\end{tabular}

${ }^{1}$ Values $<1 \%$ were assigned 0.5 , and totals were rounded to the nearest whole number.

${ }^{2}$ Richness is the number of food items in each diet discernable to species or genera.

${ }^{3}$ Samples $(n)$ are the number of pellet or pat samples included in each seasonal composite diet.

model to evaluate whether there was a significant year $x$ species interaction. Tukey's 1-degree-of-freedom tests facilitate transformation of dependent variables if significant interactions are present to improve linear models by removing interactions when MANOVA null hypotheses are rejected (Oehlert 2000). This procedure indicated that there was not enough statistical evidence to justify transforming the dependent variables to account for year $\times$ species interactions.

We used canonical variates analysis to identify the dimensionality of the MANOVA alternative hypothesis using as a criterion eigenvalues that were significantly $>0$ (Johnson 1998). When the MANOVA null hypothesis is true (i.e., $\mathrm{H}_{\mathrm{o}}$ : $\left.\mu_{1}=\mu_{2}=\cdots=\mu_{m}\right)$, all mean vectors $(\mu)$ for $m$ treatment groups lie in a 0-dimensional subspace (Johnson 1998). The canonical variates likelihood ratio test was not significant for the year effect; consequently, we conducted a single ANOVA (PROC GLM; SAS Institute 2001) with the raw canonical coefficients for both natural log ratios from the first canonical variate for the species effect as the dependent variable and year and species as independent variables. We thus pooled data over the 3 years and plotted ungulate species least squares means (ln[graminoids/browse] $\times \ln$ [forbs/browse]) from the MANOVA to depict the separation of diet means (elk in spring and elk, mule deer, cattle, and domestic sheep in summer) in 2dimensional space. Tukey-Kramer's pairwise comparisons on estimates of the first canonical variate were used to detect which species diet means differed.

We computed dietary overlap as the sum percent overlap of forage plants common to each pair of ungulate species diets, with overlap ranging from $0 \%$ to $100 \%$ (Schoener 1970; Gogan and Barrett 1995). Schoener's index is not restricted by assumptions of competition, does not change when nonutilized resources are considered, and is not sensitive to subdivision of resource states by researchers (Abrams 1980). Spearman's rank correlations (PROC CORR; SAS Institute 2001) examined the rank order of plant species in diets among ungulate pairs.

\section{Feeding Sites}

We used feeding sites to estimate standing crop and use of standing crop by elk, cattle, and domestic sheep to examine forage selection and preference in aspen and sagebrush communities in 1999 and 2000. Our experimental design was completely randomized with ungulate species (elk, cattle, and domestic sheep), plant community (aspen and sagebrush), and time period (1999 and 2000) as main effects. We sampled feeding sites in aspen and sagebrush communities, including herbaceous meadows interspersed within the sagebrush complex, to reflect the range of forage available to foraging ungulates. We used focal animal sampling (Altmann 1974) to observe behaviors of individually selected animals at group locations and defined feeding sites as those locations where we observed focal animals foraging undisturbed for at least 15 minutes. We did not sample feeding sites of mule deer. A crude map was sketched for each feeding site to guide field workers back to exact group locations to conduct sampling. Elk feeding sites used by livestock were not sampled (Irwin and Peek 1983). We found it necessary to evaluate some feeding sites used by elk 
groups with no collars because, as summers progressed, livestock had previously used most feeding sites used by groups with collared elk. We did not exclude livestock feeding sites where we detected wildlife signs because amount of wildlife use appeared to be minimal ( $<1 \%$ fresh weight). Feeding sites were examined within 1 week from observations to reduce forage regrowth biases.

We employed a double sampling technique to measure live standing crop in nested quadrats (Bonham 1989; Bureau of Land Management 1996). At each feeding site, we randomly selected 2 (1999) or 3 (2000) of the nested quadrats to achieve a clipping ratio of 1:5 (Collins and Urness 1983; Bureau of Land Management 1996) and clipped and separated all herbaceous standing crop and woody browse current annual growth in these quadrats from ground level to a height of $2 \mathrm{~m}$. Fresh weights were recorded to the nearest $0.5 \mathrm{~g}$ and weights less than $0.5 \mathrm{~g}$ (traces) were recorded as $0.1 \mathrm{~g}$.

A 0.01 -ha circular plot delineated by four $5.64-\mathrm{m}$ cords extending in the 4 cardinal directions from the center of each feeding site defined the area evaluated at each feeding site (Beck et al. 1996). Ten (1999) or 15 (2000) nested quadrats were placed in a clockwise direction along the right side of delineating cords within each plot at equidistant positions from the center of the plot, with one nested quadrat placed over the plot center. We evaluated 5 additional quadrats in feeding sites in 2000 to improve precision of our estimates. Each nested quadrat consisted of a $0.1-\mathrm{m}^{2}(20 \times 50 \mathrm{~cm})$ herbaceous quadrat nested along the bottom center of a $1.0-\mathrm{m}^{2}$ woody browse quadrat. Percentage of ungulate use and grams of residual standing crop were ocularly estimated in each nested quadrat. Live herbaceous standing-crop and shrub current annual growth were evaluated to a height of $2 \mathrm{~m}$ from the ground to account for foraging reach. Annual forbs were not included in feeding-site analyses because they formed a very small portion of consumption at feeding sites and were not detected in fecal diet compositions. Conifers were excluded from feeding-site analyses because they were not eaten.

Linear regressions using ocularly estimated fresh weights of forbs, graminoids, and woody browse categories as independent variables and clipped weights as dependent variables (PROC REG; SAS Institute 2001) for respective forage categories at feeding sites in each community and sampling period were used to calibrate ocular estimates of fresh standing crop in quadrats that were not clipped. Clipped samples were placed in paper bags and initially air dried to prevent degradation, then oven dried in a forced-air oven at $60^{\circ} \mathrm{C}$ for 24 hours, and weighed to $\pm 0.01 \mathrm{~g}$. Mean percent dry matter (DM) for each forage category from clipped quadrats at each community was multiplied by calibrated estimates of fresh weight in estimated quadrats to calculate grams DM $\cdot$ meter $^{-2}$ for ocularly estimated quadrats. We used regression equation calibrations of fresh weight in nonclipped quadrats, ocular estimates of fresh weight use, and residual live standing crop to back calculate dry, aboveground standing crop prior to herbivory to provide estimates of forage availability in feeding sites. Live standing crop for unclipped quadrats was computed as calibrated fresh weight $(\mathrm{g}) /(1-$ [percent use of fresh weight/100]) $\times$ percent DM. Live standing crop for clipped quadrats was computed as clipped dry weight $(\mathrm{g}) /(1$ - [percent use of fresh weight/100]). Herbaceous standing crop ingested (grams) and standing crop (grams) prior to herbivory in $0.1-\mathrm{m}^{2}$ quadrats were multiplied by 10 to compare with woody browse grams DM $\cdot$ meter $^{-2}$. At each feeding site, mean grams DM $\cdot$ meter $^{-2}$ ingested for each category was divided by the sum of grams DM. meter ${ }^{-2}$ ingested to compute mean proportions of perennial forbs, perennial graminoids, and woody browse consumed by foraging ungulates.

\section{Feeding-Site Statistical Analyses}

Forbs, graminoids, and browse consumed by each ungulate were transformed into 2 dependent variables through natural$\log$ ratios of proportions of forbs to browse ( $\ln [$ forbs/browse]) and proportions of graminoids to browse (ln[graminoids/ browse]). Zero values were assigned a value of 0.001 to avoid computational problems when dividing by zeroes. Natural log ratios were assessed for assumptions of MANOVA, including multivariate normality and covariance homogeneity. We used MANOVA to evaluate the effect of species, community, and time period on selection of natural log of forage ratios. The period main effect and the species $\times$ period and species $\times$ period $\times$ community interactions were not significant, which allowed us to pool ungulate forage-selection ratios in aspen and sagebrush communities across time periods. We used canonical variates analysis to identify the dimensionality of the alternative hypothesis of the species $\times$ community MANOVA model (see Dietary Statistical Analyses). We used an ANOVA with the raw canonical coefficients for both natural log ratios from the first canonical variate for the species $\times$ community interaction as the dependent variable and species, period, community, species $\times$ community, and period $\times$ community as independent variables to detect differences in forage selection group (i.e., ungulate species $\times$ community type) means in aspen and sagebrush communities (Johnson 1998).

We used separate ANOVAs to evaluate differences in feedingsite standing crop by forage categories. Because we detected no species $\times$ period $\times$ community interaction in forage selection at feeding sites, we classified feeding sites as types (ungulate species and plant community) to examine differences in standing crop available to ungulates prior to herbivory. Main effects were feeding-site type and year, and type $\times$ year was the single interaction in models. Forb and woody browse proportionate live standing crop were arcsine square-root transformed to meet assumptions of normality and equal variance prior to statistical testing (Fowler et al. 1998). We report proportionate standing crop as raw estimates \pm standard error (SE).

We used Ivlev's electivity index (Ivlev 1961) to evaluate preference for forbs, graminoids, and woody browse at elk, cattle, and sheep feeding sites in aspen and sagebrush communities. Ivlev's (1961) index relates use of forage items to their availability in environments ([used - available]/[used + available]). Electivity varies from -1.0 to +1.0 , with values from 0.0 to 1.0 indicating preference and values between -1.0 and 0.0 indicating avoidance of forage items. Electivity values of 0.0 indicate forage items were used in proportion to their availability.

\section{Alkaloid Content in Spurred Lupine}

Spurred lupine was collected from 3 cattle grazing allotments during 3 periods (late June, early August, and late September) in 1999 and 2000, yielding a total of 18 samples. We clipped 
segments of ungrazed plants to mimic portions observed eaten at feeding sites, which typically included flowers and surrounding leaves as well as some basal leaves. At each collection, we clipped fresh material and removed old growth to form $\geq 30$-g samples from a minimum of 5-10 plants to encompass variation among plants. Composite samples were air dried in paper bags to prevent fungal growth and later dried for 24 hours in a forced-air oven at $60^{\circ} \mathrm{C}$. Oven-dried samples were ground to $2 \mathrm{~mm}$ and stored in plastic bags at room temperature. Ground lupine from each composited sample was separated into duplicate samples prior to laboratory analyses.

Personnel at the (USDA-ARS Poisonous Plant Research Laboratory in Logan, Utah, determined total and individual alkaloids with gas chromatography (Hewlett Packard 5890; Agilent, Palo Alto, CA) according to Gardner and Panter (1993) and Lopez-Ortiz et al. (2004). Alkaloid peaks, retention times, and peak areas were compared with 2 standard plant samples: L. caudatus Kellogg (USDA accession No. 87-3), which contained quinolizidine alkaloids; and Lupinus formosus Greene (USDA accession No. 82-7), which contained piperidine alkaloids (Gardner and Panter 1993, 1994). Peak identifications were based on gas chromatography/mass spectroscopy analysis (Thermo-Finnigan, Austin, TX) and comparison of retention times with those alkaloid peaks from the standard plant samples. The interassay variation of 85 replicates from 1999 to 2004 was < 5\% (T. Weierenga, USDA-ARS Poisonous Plant Research Laboratory, Logan, Utah, unpublished data). The limit of detection for individual and total alkaloids was $0.025 \mathrm{mg} \cdot 100 \mathrm{mg}^{-1}$. We averaged duplicate samples to estimate total alkaloids in each composite lupine sample and then averaged these values for all 3 allotments during each period to compute mean total alkaloids $\left(\mathrm{mg} \cdot 100 \mathrm{mg}^{-1}\right) \pm \mathrm{SE}$ by period.

\section{RESULTS}

\section{Diet Composition}

Elk largely ate forbs $(59 \%-78 \%)$ in summer, while elk diets in spring were composed of a variety of graminoids $(18 \%-60 \%)$, forbs $(30 \%-55 \%)$, and browse $(10 \%-35 \%$; Fig. 1$)$. Mule deer diets for all 3 summers were composed of about $30 \%$ browse, $64 \%-72 \%$ forbs, and $2 \%-5 \%$ graminoids. Cattle diets were dominated by graminoids ( $\geq 92 \%$ ) over all summers (Fig. 1 ). Sheep diets consisted of little browse $(<1 \%-5 \%)$, about $70 \%$ graminoids, and $23 \%$ forbs in 1998 and 1999, and then decreased to $42 \%$ graminoids and increased to $58 \%$ forbs in 2000 (Fig. 1). Rank order of mean forage plant species richness in diets from 1998 to 2000 was spring elk (34) > summer elk (30) > mule deer (28) > sheep (24) > cattle (21; Table 1).

Lupines (Lupinus spp. L.) formed $\geq 11 \%$ of elk, deer, and sheep diets over all summers (Table 1). Twelve forage species accounted for $45 \%-87 \%$ of all diets, and 6 grass species contributed $52 \%-82 \%$ to cattle diets and $40 \%-59 \%$ to sheep diets (Table 1). Forbs were arrowleaf balsamroot (Balsamorhiza sagittata [Pursh] Nutt.) and lupines (Lupinus spp. L.); grasses were bluebunch wheatgrass (Pseudoroegneria spicata [Pursh] A. Löve), Idaho fescue (Festuca idahoensis Elmer), Kentucky bluegrass (Poa pratensis L.), mountain brome (Bromus marginatus Nees ex Steud.), needlegrasses (Achnatherum spp. Beauv.), and Sandberg bluegrass (Poa secunda J. Presl);

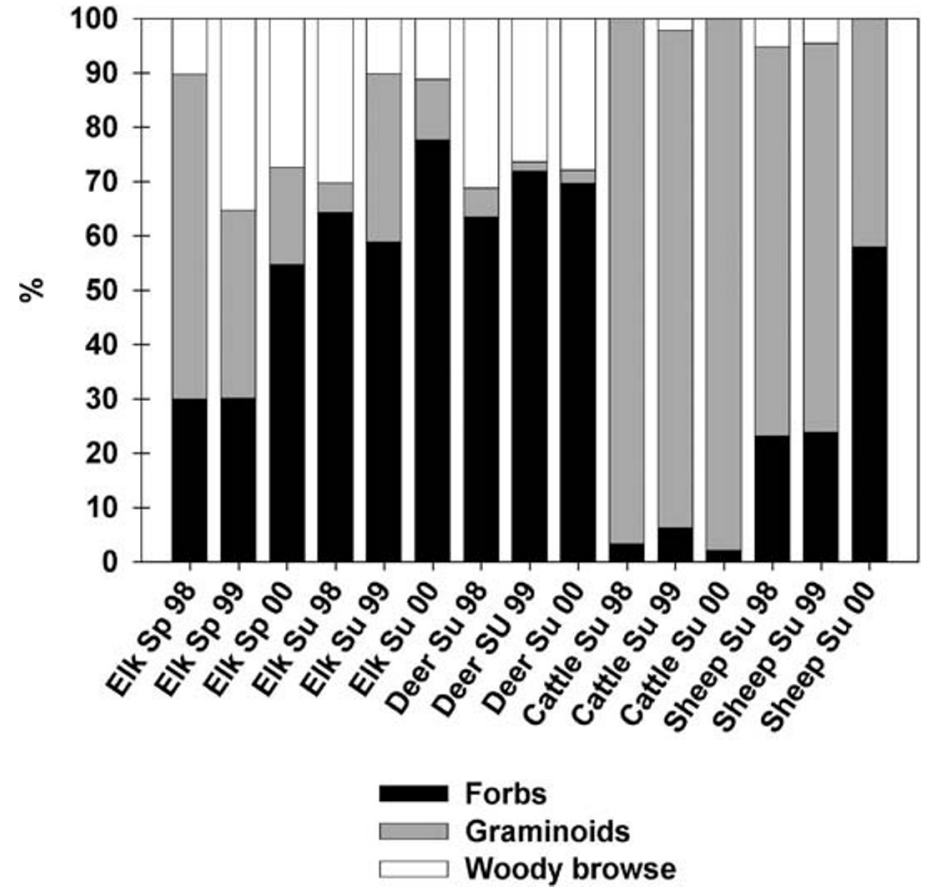

Figure 1. Composition (\%) of forbs, graminoids, and woody browse in elk, mule deer, cattle, and domestic sheep diets, Jarbidge Mountains, Nevada, 1998-2000. Seasons are spring (Sp; late May through 9 July) and summer (Su; 10 July through mid-September). Spring elk diet samples include cow-only and mixed-sex elk groups. Forbs may include small amounts of moss, lichens, or unidentified seeds. Forbs in 2000 elk spring diets include $0.5 \%$ insect remains.

and woody species were aspen, curlleaf mountain mahogany, mountain snowberry (Symphoricarpos oreophilus Gray), and snowbrush ceanothus (Table 1).

Residual by predicted plots to assess homogeneity of variances and normal quantile plots to assess normality for each dependent variable revealed that the sheep 2000 diet had a large influence on covariance homogeneity and multivariate normality and was thus not considered in the MANOVA analysis. We detected a difference in diet composition among ungulate species (Wilk's $\Lambda=0.02, F_{8,12}=8.45, P=0.001$ ), but not between years (Wilk's $\Lambda=0.51, \quad F_{4,12}=1.22$, $P=0.355$ ). Least squares mean ratios of graminoids to browse were highest in cattle and domestic sheep diets. Mule deer diets were lowest in the ratio of graminoids to browse (Fig. 2). Diets of mule deer in summer and elk in spring composed a lower natural $\log$ ratio of forbs to browse than cattle, domestic sheep, or elk in summer (Fig. 2).

The canonical variates likelihood ratio test for year was not significant $(P=0.355)$, whereas the canonical variates likelihood ratio test for species indicated the dimensionality of the alternative hypothesis was 1 , as only the first canonical variate was significant $(P<0.001)$. Cumulative variation $(92.3 \%)$ for the eigenvalue of the first canonical variate indicated ungulate species fell along a single axis, further indicating that only 1 canonical variate was required to separate ungulate diets. Means differed $(P=0.001-0.045)$ between all diet pairs, except elk in spring with sheep, elk in summer with mule deer and sheep, and cattle with sheep (Table 2). 


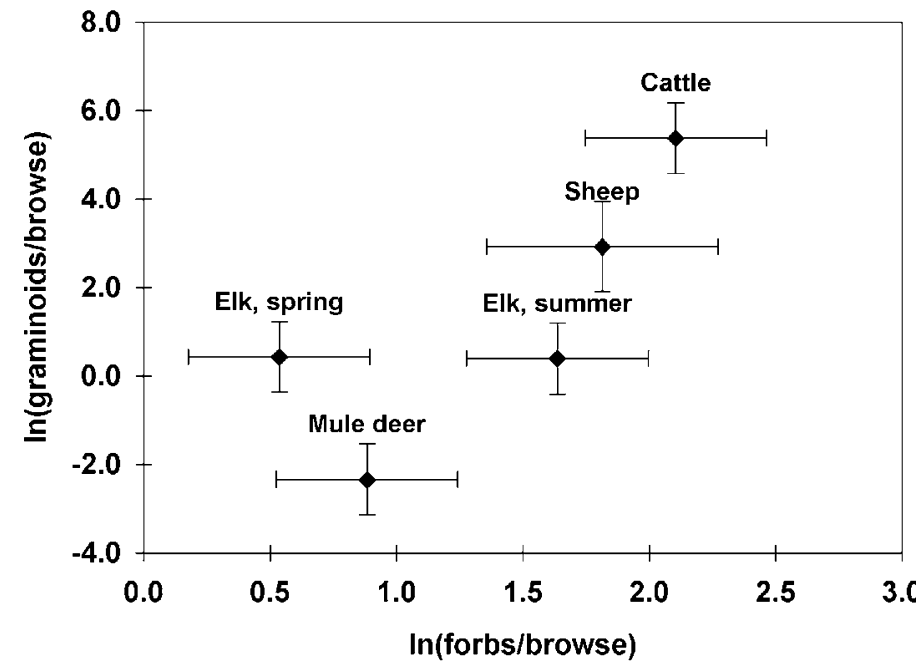

Figure 2. Elk, cattle, domestic sheep, and mule deer natural log diet ratios (least squares means \pm standard error), Jarbidge Mountains, Nevada. Means were averaged over 1998-2000 and are presented as diamonds. Mean natural log ratios of graminoids to browse (In[graminoids/browse]) plotted on the $y$-axis and mean natural log ratios of forbs to browse (In[forbs/browse]) plotted on the x-axis. $P$ values comparing differences between diets are reported in Table 2.

Highest diet overlap was between cattle and sheep in 1999 $(68 \%)$ and lowest overlap was between mule deer and cattle in $2000(3 \%)$. Elk and deer diets moderately overlapped $(45 \%-$ $59 \%$ ) in summer (Table 3 ). Sheep diets moderately overlapped elk diets in spring $(31 \%-42 \%)$ and summer $(22 \%-65 \%)$, and spring elk diets moderately overlapped cattle diets $(14 \%-46 \%$; Table 3).

\section{Forage Selection}

We evaluated forage selection at 36 elk (22 in 1999, 14 in 2000), 42 cattle ( 21 in 1999, 21 in 2000), and 25 domestic sheep (10 in 1999,15 in 2000) feeding sites. We detected differences in forage selection at feeding sites for species (Wilk's $\Lambda=0.62$, $F_{4,180}=12.09, P<0.001$ ) and community (Wilk's $\Lambda=0.93$, $\left.F_{2,90}=3.35, P=0.040\right)$ main effects, and species $\times$ community (Wilk's $\Lambda=0.89, F_{4,180}=2.81, P=0.027$ ) and period $\times$ community (Wilk's $\Lambda=0.84, F_{6,180}=2.80, P=0.013$ ) interactions. Tukey-Kramer pairwise comparisons of canonical variates least squares means indicated forage selection ratios for all

Table 2. $P$-values between elk, mule deer, cattle, and domestic sheep natural log diet ratios, Jarbidge Mountains, Nevada, 1998-2000. Differences assessed with ANOVA through Tukey-Kramer pairwise comparisons of the first canonical variate. Diets were averaged across years, means are plotted in Figure 2, and differ when $P<0.05$.

\begin{tabular}{lcccc}
\hline Diet & Elk, spring & Elk, summer & Mule deer & Cattle \\
\hline Elk, spring & - & - & - & - \\
Elk, summer & 0.045 & - & - & - \\
Mule deer & 0.003 & 0.189 & - & - \\
Cattle & 0.034 & $<0.001$ & $<0.001$ & - \\
Sheep & 0.997 & 0.053 & 0.004 & 0.094 \\
\hline
\end{tabular}

Table 3. Diet overlap between elk, mule deer, cattle, and domestic sheep, Jarbidge Mountains, Nevada, 1998-2000. Overlap calculated as sum percentage of diet species common to each ungulate pair (Schoener 1970). Spearman's rank correlations $\left(r_{\mathrm{s}}\right)$ examine the rank order of plant species in ungulate diet pairs.

\begin{tabular}{|c|c|c|c|c|c|c|}
\hline \multirow[b]{2}{*}{ Comparison } & \multicolumn{2}{|c|}{$1998^{1}$} & \multicolumn{2}{|c|}{$1999^{2}$} & \multicolumn{2}{|c|}{$2000^{3}$} \\
\hline & $\begin{array}{c}\text { Overlap } \\
(\%)\end{array}$ & $r_{s}$ & $\begin{array}{c}\text { Overlap } \\
(\%)\end{array}$ & $r_{\mathrm{s}}$ & $\begin{array}{c}\text { Overlap } \\
(\%)\end{array}$ & $r_{\mathrm{s}}$ \\
\hline Elk, spring-elk, summer & 18 & 0.18 & 33 & 0.16 & 39 & 0.25 \\
\hline Elk, spring-mule deer & 25 & $0.45^{5}$ & 32 & 0.25 & 46 & $0.31^{4}$ \\
\hline Elk, spring-cattle & 46 & $0.34^{5}$ & 37 & $0.45^{5}$ & 14 & 0.20 \\
\hline Elk, spring-sheep & 42 & $0.36^{5}$ & 37 & $0.33^{4}$ & 31 & 0.20 \\
\hline Elk, summer-mule deer & 59 & $0.39^{5}$ & 45 & 0.01 & 50 & 0.16 \\
\hline Elk, summer-cattle & 6 & -0.08 & 30 & 0.19 & 26 & $0.39^{5}$ \\
\hline Elk, summer-sheep & 22 & 0.15 & 43 & $0.37^{5}$ & 65 & $0.55^{6}$ \\
\hline Mule deer-cattle & 6 & 0.05 & 8 & -0.14 & 3 & -0.08 \\
\hline Mule deer-sheep & 20 & 0.17 & 24 & -0.02 & 50 & 0.10 \\
\hline Cattle-sheep & 59 & $0.71^{6}$ & 68 & $0.70^{6}$ & 40 & $0.66^{6}$ \\
\hline
\end{tabular}

${ }^{1}$ Number of pairwise food items compared $(n)$ was 59 for spring elk and 60 for all other diets. ${ }^{2}$ Number of pairwise food items compared $(n)$ was 53 for all diets.

${ }^{3}$ Number of pairwise food items compared $(n)$ was 55 for all diets.

${ }^{4} p<0.05$.

${ }^{5} P<0.01$

${ }^{6} P<0.001$.

ungulate species differed $(P<0.01)$. The canonical variates likelihood ratio test for the species $\times$ community interaction indicated the dimensionality of the alternative hypothesis was 1 , as only the first canonical variate was significant $(P<0.05)$. Cumulative variation $(84.5 \%)$ for the eigenvalue of the first canonical variate indicated species $\times$ community forage selection means fell along a single axis, further indicating that 1 canonical variate adequately separated species $\times$ community forage selection groups.

Elk selected more forbs in sagebrush feeding sites $(76 \%)$ than they did at aspen feeding sites $(62 \%)$. Cattle selected substantially more forbs in aspen feeding sites $(68 \%)$ than in sagebrush feeding sites $(11 \%)$, while cattle consumption at feeding sites in sagebrush was composed of $88 \%$ graminoids (Fig. 3). Forage selection by sheep remained more constant between the 2 communities but was composed of slightly more forbs in aspen communities $(45 \%)$ than in sagebrush communities (36\%; Fig. 3). Elk consumed spurred lupine at 10 of 23 feeding sites where spurred lupine grew, cattle at 16 of 28 feeding sites with spurred lupine, and sheep at 15 of 16 feeding sites where we detected spurred lupine.

Natural log ratios of forbs to browse were highest for cattle foraging in aspen and were lowest for sheep selecting forage in sagebrush feeding sites (Fig. 4). Natural log ratios of graminoids to browse were highest for cattle foraging in aspen and lowest for elk foraging in sagebrush (Fig. 4). Tukey-Kramer pairwise comparisons of canonical variates species $\times$ community forage selection groups indicated forage selection of elk feeding in aspen and sagebrush differed $(P<0.01)$ from cattle and sheep feeding in sagebrush (Table 4). Forage selection of cattle feeding in aspen differed from sheep feeding in sagebrush $(P=0.030)$. Significance $(P=0.055)$ between cattle forage selection ratios in aspen and sagebrush suggests cattle forage 


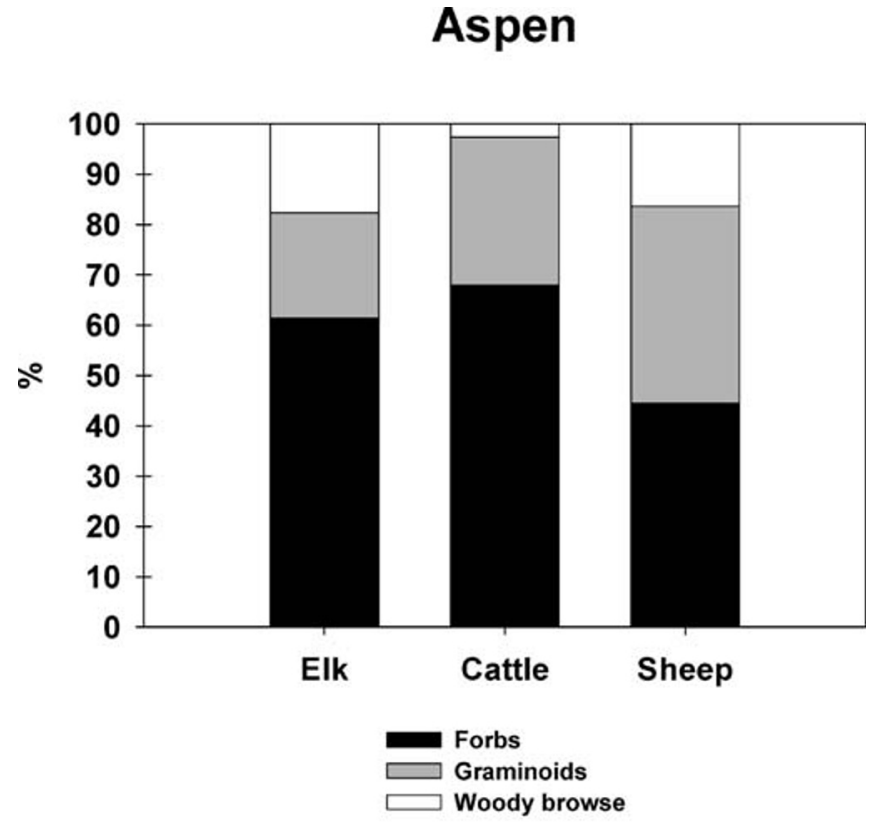

\section{Sagebrush}

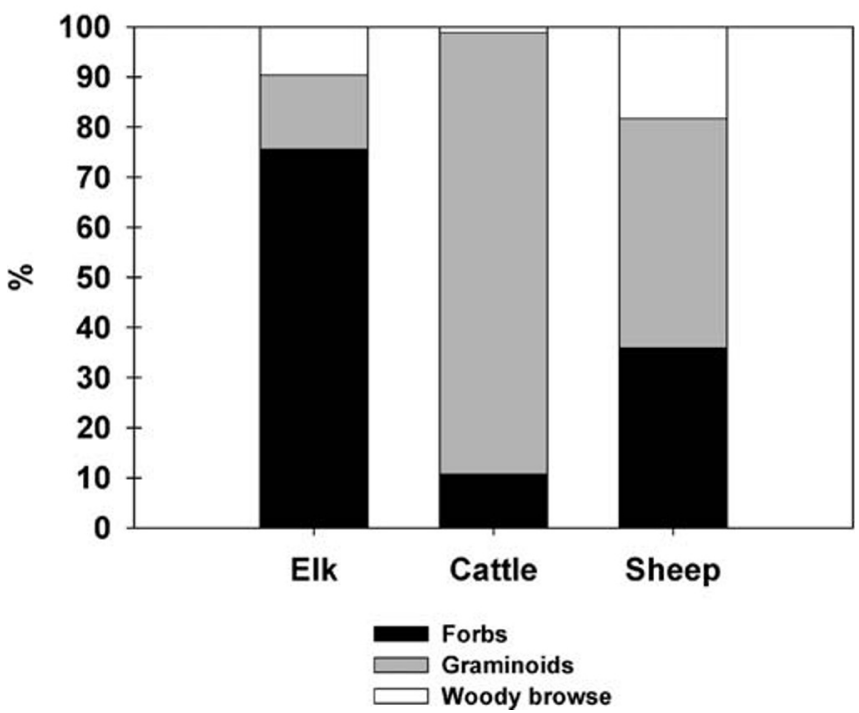

Figure 3. Composition (\%) of forbs, graminoids, and woody browse selected by elk, cattle, and domestic sheep at feeding sites in aspen and sagebrush communities, Jarbidge Mountains, Nevada. Composition of forage selected based on mean $\mathrm{g}$ dry matter $\cdot \mathrm{m}^{-2}$ consumed by ungulates at feeding sites averaged over 1999 and 2000.

selection differed between both communities, particularly for forbs (Table 4; Fig. 4). We detected no differences in elk, cattle, and sheep forage selection means in aspen feeding sites (Table 4).

Feeding-site type $\times$ year interactions did not differ for forb, graminoid, and woody browse availabilities in feeding sites $(P>0.05)$, providing justification to pool availability data across years (Table 5). Feeding-site type was a significant $(P<0.01)$ main effect in all models. Year was only a significant $(P=0.041)$ main effect in the graminoid-availability model with graminoid availability being higher in 1999 than 2000 .

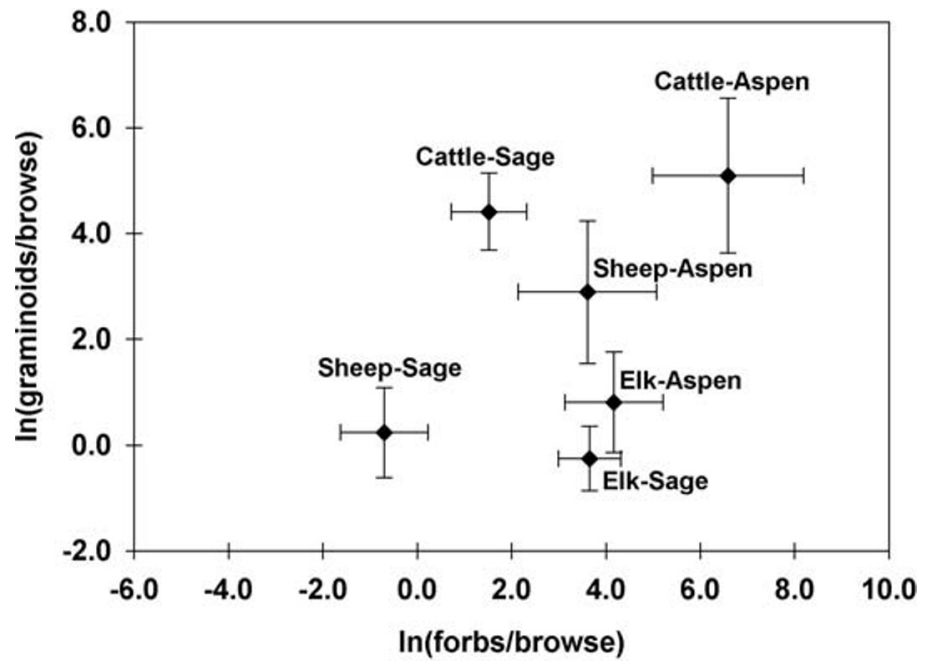

Figure 4. Elk, cattle, and domestic sheep natural log forage selection ratios (least squares means \pm standard error) at feeding sites in aspen and sagebrush communities, Jarbidge Mountains, Nevada. Means were averaged over 1999 and 2000 and are presented as diamonds. Mean natural log ratios of graminoids to browse (In[graminoids/browse]) plotted on the $y$-axis and mean natural log ratios of forbs to browse (In[forbs/browse]) plotted on the $x$-axis. $P$-values comparing differences between ungulate species $\times$ community-type forage selection groups are reported in Table 4.

However, we do not show means by year for simplicity of data presentation. Forb availability in sagebrush was lowest at feeding sites selected by cattle and sheep (Table 5). Graminoid availability was highest at cattle feeding sites in sagebrush, which did not differ from graminoids at sheep feeding sites. Woody browse was lowest in proportionate availability at all feeding sites, except for sheep in sagebrush communities, where forbs were lowest (Table 5).

Electivity indices indicate elk had a slightly higher preference for forbs in sagebrush $(+0.19)$ communities compared with aspen (+ 0.16; Fig. 5). Cattle demonstrated a slight preference for graminoids in sagebrush communities $(+0.19)$. Sheep slightly preferred forbs in aspen communities $(+0.10)$. All other electivity indices were negative, but greater than -1.0 , suggesting ungulates selected a diversity of forage, but focused

Table 4. $P$-values between natural log forage ratios selected by elk, cattle, and domestic sheep at feeding sites in aspen and sagebrush (sage) communities, Jarbidge Mountains, Nevada, 1999 and 2000. Differences assessed with ANOVA through Tukey-Kramer pairwise comparisons of the first canonical variate. Natural log ratio means were averaged across years, are plotted in Figure 4 and differ when $P<0.05$.

Comparison Elk-aspen Elk-sage Cattle-aspen Cattle-sage Sheep-aspen

\begin{tabular}{lccccc}
\hline Elk-aspen & - & - & - & - & - \\
Elk-sage & 1.000 & - & - & - & - \\
Cattle-aspen & 0.999 & 0.998 & - & - & - \\
Cattle-sage & 0.009 & $<0.001$ & 0.055 & - & - \\
Sheep-aspen & 0.748 & 0.916 & 0.657 & 0.544 & - \\
Sheep-sage & 0.004 & $<0.001$ & 0.030 & 0.974 & 0.371 \\
\hline
\end{tabular}


Table 5. Proportionate availability (mean \pm standard error) of perennial forb, perennial graminoid, and woody browse standing crop at elk, cattle, and domestic sheep feeding sites in aspen and sagebrush communities, Jarbidge Mountains, Nevada, 1999 and 2000. Estimates represent live standing crop prior to herbivory and are averaged over 1999 and 2000.

\begin{tabular}{lrccc}
\hline Species and community & $n$ & Forbs & Graminoids & Woody browse \\
\hline Elk & & & & \\
$\quad$ & 13 & $0.44 \pm 0.08^{1,2}$ & $0.31 \pm 0.07^{1}$ & $0.25 \pm 0.05^{1,2}$ \\
$\quad$ Aspen & 23 & $0.52 \pm 0.06^{1}$ & $0.31 \pm 0.05^{1}$ & $0.17 \pm 0.03^{1,2}$ \\
$\quad$ Sagebrush & & & & \\
Cattle & 5 & $0.61 \pm 0.14^{1}$ & $0.29 \pm 0.09^{1}$ & $0.11 \pm 0.05^{1,2}$ \\
$\quad$ Aspen & 37 & $0.25 \pm 0.03^{2}$ & $0.61 \pm 0.03^{2}$ & $0.14 \pm 0.02^{1}$ \\
$\quad$ Sagebrush & & & \\
Sheep & 8 & $0.36 \pm 0.11^{1,2}$ & $0.33 \pm 0.08^{1}$ & $0.31 \pm 0.06^{1,2}$ \\
$\quad$ Aspen & 17 & $0.25 \pm 0.04^{2}$ & $0.48 \pm 0.06^{1,2}$ & $0.27 \pm 0.04^{2}$ \\
$\quad$ Sagebrush & & & \\
$\begin{array}{l}1,2 \\
\text { Estimates in the same column followed by the same superscript are not different } \\
(P>0.05) \text { as tested by Tukey-Kramer pairwise comparison tests. }\end{array}$
\end{tabular}

on a single forage category in each community (Fig. 5). Use was nearly equal to availability for forbs selected by cattle in aspen feeding sites and forbs selected by sheep in sagebrush feeding sites. Although electivity indices suggest avoidance, elk elected to consume browse at slightly higher rates than graminoids in both communities, and cattle avoided browse in both communities at levels higher than for forbs (Fig. 5).

\section{Alkaloids in Spurred Lupine}

Total alkaloids (mean \pm SE mg $\cdot 100 \mathrm{mg}^{-1}$ ground sample) in spurred lupine were $2.98 \pm 1.23$ (range $=0.58-4.61)$ in late June 1999, $0.58 \pm 0.11$ (range $=0.42-0.78$ ) in late June 2000, $0.19 \pm 0.06$ (range $=0.09-0.29$ ) in early August 1999, and $0.26 \pm 0.13$ (range $=0.11-0.52$ ) in early August 2000. Total alkaloids in spurred lupine were below detectable levels by late September in all samples except in 1 grazing allotment in 1999 $\left(0.06 \mathrm{mg} \cdot 100 \mathrm{mg}^{-1}\right)$. Highest total alkaloids (4.61 and 3.76 $\mathrm{mg} \cdot 100 \mathrm{mg}^{-1}$ ) were detected in samples from 2 grazing allotments in late June 1999. By comparison, total alkaloid content in 1 sample of rolled lupine (Lupinus lepidus aridus [Dougl.] Jepson) collected in July 1998 was below detectable levels and total alkaloids in one sample of sulphur lupine (Lupinus sulphureus Dougl. ex Hook.) collected in mid-July 1999 was $1.63 \mathrm{mg} \cdot 100 \mathrm{mg}^{-1}$ of ground sample.

\section{DISCUSSION}

\section{Diet Composition and Overlap}

A potential weakness of composite fecal samples is a loss of sample variability compared with individual samples. In our study, compositing fecal samples and then evaluating cover of plant fragments from 8 slides quantified the variability associated with compositing but not the variability between individual diets. However, there were no statistical differences among years in each ungulate's composite diet over 3 summers. Forage selection at feeding sites further substantiated patterns
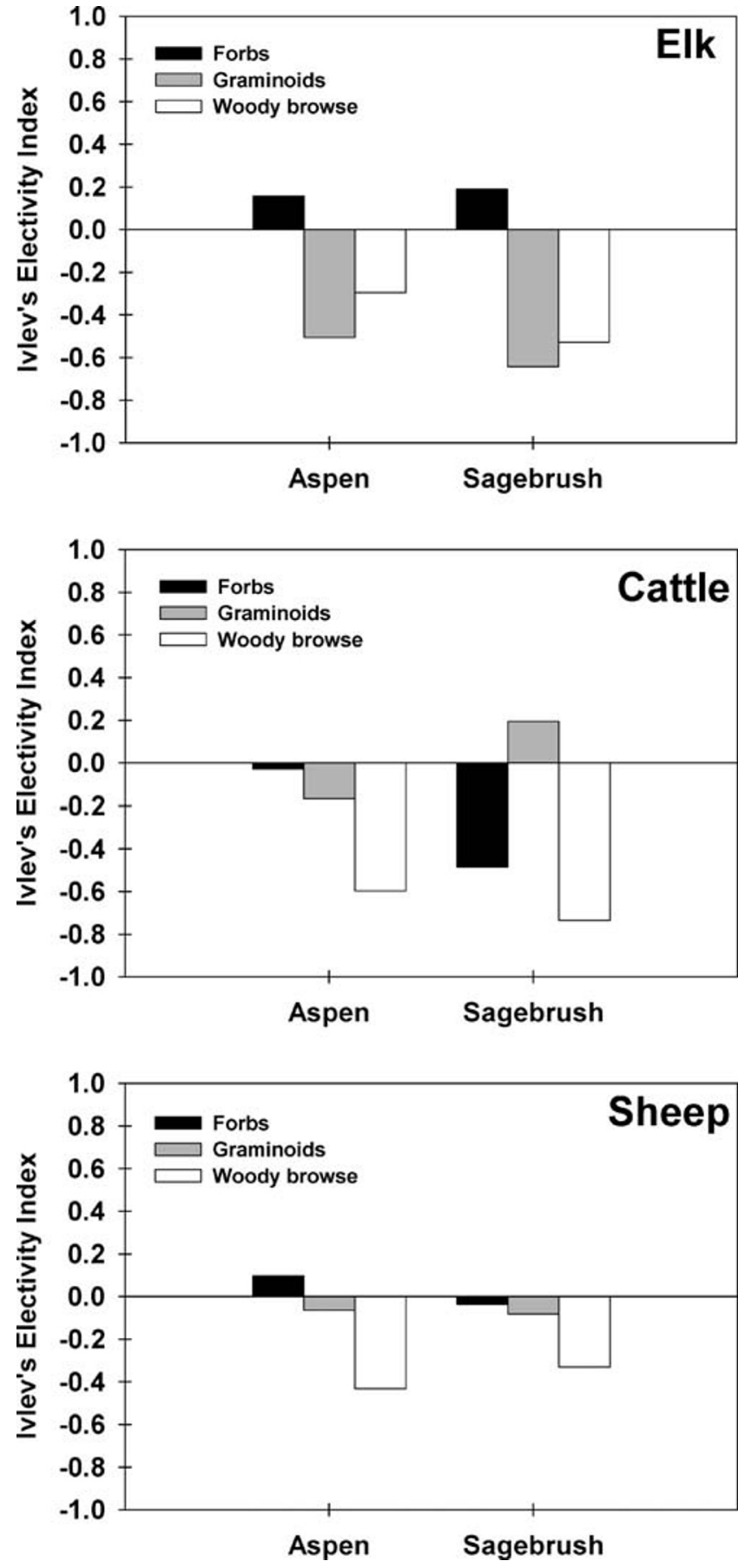

Figure 5. Ivlev's electivity indices for elk, cattle, and domestic sheep forage selection in aspen and sagebrush communities, Jarbidge Mountains, Nevada. Indices based on dry matter consumption $\cdot \mathrm{m}^{-2}$ at feeding sites averaged over 1999 and 2000. Electivity values from 0.0 to +1.0 indicate preference, 0.0 to -1.0 indicate avoidance, and 0.0 indicate forage items were used in proportion to their availability.

in composite fecal samples. Composite sampling thus provided us a cost-effective way to obtain reliable results across years.

There were reportedly 560000 domestic sheep as well as cattle and horses grazing the Jarbidge and adjacent Independence and Gold Creek Ranger Districts in 1908 (Gruell 1998). Historical and excessive cattle herbivory on the Wasatch 
Plateau in central Utah caused ranges to be dominated by forbs and high sheep grazing pressure created ranges composed largely of grasses (Ellison 1954). Consequently, we believe historically high levels of sheep grazing in the Jarbidge Mountains influenced composition and productivity in many communities, particularly for forbs, which are favored by sheep. Current diet patterns may reflect plant community composition as influenced by past livestock grazing, particularly domestic sheep. Composition and productivity of aspen and sagebrush communities should accordingly be evaluated with historical grazing practices in mind.

We would predict higher diet overlap during dry summers among elk, sheep, and mule deer, when forb nutrients and availabilities are reduced. By comparison, diet overlap between tule elk (Cervus elaphus nannodes) and black-tailed deer (Odocoileus bemionus columbianus) in northern California was highest during dry summer months, when fecal nitrogen was lowest and both species simultaneously selected forbs (Gogan and Barrett 1995). Similarly, pronghorn and livestock diet overlap was greatest in north-central New Mexico during a dry year when forage availability was reduced (Stephenson et al. 1985). The ability of generalist herbivores, such as sheep and elk, to adjust diets to changing forage availabilities in dry summers (Bugalho and Milne 2002) could increase diet overlap in dry years. Warm, windy weather in late spring and early summer 2000 in our study area limited growth and hastened maturity of herbaceous forage. Elk and sheep both demonstrated plasticity in diets in response to foraging conditions by foraging on more forbs in summer 2000 than in 1999 or 1998, leading to elevated diet overlap. In addition, elk in spring and elk in summer, elk and deer in spring, and deer and sheep diet overlap were highest in 2000, when conditions warmer and drier than normal affected forage conditions.

\section{Forage Selection}

Our results indicate that certain foraging situations among ungulates on aspen-sagebrush summer ranges could lead to competition. Potential for forage competition should be viewed in light of relative availability of plant communities. For instance, the high proportion of graminoids in cattle diets likely reflected the fact that sagebrush communities, where graminoid production in feeding sites was higher than in aspen, covered $83 \%$ of the Black Spring/Caudle Creek and $69 \%$ of the Pole Creek allotments. The relatively low availabilities of aspen $($ Black Spring $/$ Caudle Creek $=9 \%$; Pole Creek $=11 \%)$ in these allotments could lead to higher diet overlap in aspen communities between cattle and other ungulates. Use of forbs by cattle in aspen communities was proportional to availability, a relationship that has been documented in forb-dominated communities (Ralphs and Pfister 1992). Overlap in forage selection was most evident in aspen communities, where we detected no differences among elk, cattle, and sheep. Our results suggest greatest potential for forage competition among elk, mule deer, cattle, and domestic sheep is for forbs in aspen communities.

\section{Lupines and Alkaloids}

We identified rolled, spurred, and sulphur lupine in the Jarbidge Mountains. Spurred lupine grew in aspen and sagebrush communities; was the most abundant lupine on summer range; and was frequently eaten by elk, cattle, and sheep at feeding sites. Rolled and sulphur lupines were rarely eaten by ungulates and sulphur lupine tended to be distributed at lower elevations. Although species-level identification of lupines in microhistological analysis was not possible, feeding-site evidence indicates spurred lupine was the most common lupine selected.

Total alkaloid levels in excess of $0.5 \%$ (i.e., $0.5 \mathrm{mg} \cdot 100 \mathrm{mg}^{-1}$ ) can present potential problems to foraging ungulates (K. Panter, USDA-ARS Poisonous Plant Research Laboratory, Logan, Utah, personal communication, 2004); lupines in our study only exceeded these levels in late June. Spurred lupine contains toxic alkaloids that have been reported to cause cattle deaths and skeletal birth defects (Kingsbury 1964). Domestic sheep are about 3-5 times more resistant to the toxicity of lupine alkaloids than cattle, and skeletal birth defects rarely occur in lambs born to ewes that ingest lupine while pregnant; however, concentrated sheep grazing on seedpods in late summer, when they contain up to $3 \%-$ $4 \%$ alkaloids, has led to death on many occasions (K. Panter, USDA-ARS Poisonous Plant Research Laboratory, Logan, Utah, personal communication, 2004). Teratogenic alkaloids including anagyrine and ammodendrine have been identified, but anagyrine is recognized as the principal alkaloid causing crooked-calf disease (Keeler 1976). Some lupines are valuable or highly valuable elk forage, while many have limited forage value for elk (Cook 2002). Crooked-calf disease apparently does not occur in wild ungulates and lupine ingestion in our study was below what would be considered toxic levels to elk or mule deer (K. Panter, USDA-ARS Poisonous Plant Research Laboratory, Logan, Utah, personal communication, 2004).

Alkaloids in lupines produce bitter tastes and levels are highest early in the growing season and in mature pods (Cheeke 1998). By comparison, highest total alkaloid levels in spurred lupine in our study were in late June 1999. Colder temperatures and snow pack lasted longer in 1998 and 1999 than in 2000, delaying plant phenology and potentially influencing alkaloid levels and thus subsequent acceptability of lupines to foraging ungulates. Elk consumed 5.7 and 2.8 times more lupines in spring 2000 than in spring 1998 and 1999, respectively. Greater consumption in spring 2000 may have been related to lower alkaloid levels in lupines with more advanced phenology than in previous years.

Spurred lupine is valuable forage in the Jarbidge Mountains because it maintains crude protein through late September and digestible energy through early August at levels exceeding lactating cow elk requirements (Beck 2003). Nutritional benefits of spurred lupine in our study area apparently exceeded any deleterious effects. Mule deer may rely heavily on 1 or 2 plant species when other forages lack adequate protein in late summer (Austin and Urness 1985), and herd productivity in 2 southeastern Utah mule deer populations was related to differences in quantity and quality of forbs on summer range (Pederson and Harper 1978). Elk on aspen-sagebrush summer range in northcentral Utah consumed greater quantities of aspen bluebells (Mertensia arizonica Greene), the dominant forage species selected in feeding sites, in late spring, when crude protein levels were higher than in summer (Beck et al. 1996). Likewise, high consumption of lupines by elk and deer in our study appears to be related to high nutritional quality relative to other forages. Lupines in elk diets in summers 1998, 1999, and 2000 
were $13.7,4.8$, and 2.2 times higher than respective composition in spring diets, corresponding with higher summer levels of crude protein and digestible energy than grasses and higher crude protein than woody browse (Beck 2003), and when total alkaloids were lower than in spring.

\section{MANAGEMENT IMPLICATIONS}

Our study indicates forbs are a fundamental component of elk, cattle, mule deer, and domestic sheep diets on shared aspensagebrush summer range. Efforts to reduce forbs or browse to increase grass forage would negatively affect foraging opportunities for these ungulates. Thus, managers must maintain high diversity and abundance of plants on shared aspensagebrush summer range.

Cattle and sheep grazing the same allotment at the same time would be especially inappropriate given their high degree of diet overlap and selection of graminoid-rich diets in sagebrush communities. Dual stocking of aspen-sagebrush summer ranges with cattle and sheep would likely lead to overuse of favored forage plants. A potential conflict could arise between moderate- or high-density elk populations and mule deer populations during summer due to the magnitude of diet overlap and the fact that we did not detect differences in deer and elk diets at low elk densities. High-density elk populations could elevate diet overlap with mule deer and sheep and possibly cattle and lead to competitive interactions. Managers should monitor ungulate populations on aspensagebrush summer range to manage for levels that avoid declines in important forage resources.

Monitoring productivity and use of key forage species, particularly forbs in aspen communities, should also complement management objectives on shared aspen-sagebrush summer range. Eight forbs that grow in aspen communities contributed $\geq 2 \%$ to at least 1 ungulate diet for at least 2 years during our study. We therefore recommend monitoring the following key forb species in aspen communities on shared summer range in northeastern Nevada: avens (Geum spp. L.), bluebells (Mertensia spp. Roth), cinquefoil (Potentilla spp. L.), lupines, sticky purple geranium (Geranium viscosissimum Fisch. \& C.A. Mey. ex C.A. Mey.), violets (Viola spp. L.), western stoneseed (Lithospermum ruderale Dougl. ex Lehm.), and western yarrow (Achillea millefolium L. var. occidentalis DC.). Managers should be familiar with important forbs in aspen communities in various regions due to the great diversity of forbs growing under aspen across its range of distribution (Mueggler 1988).

We found that total alkaloid levels in spurred lupine declined over summer and that ungulates selected lupines in mid- to late summer when total alkaloid levels were lower than in late June and when they were below potentially toxic levels. Spurred lupine was widespread in aspen and sagebrush communities and also inhabited disturbed sites, such as burns and areas covered with large snow banks during winter. While spurred lupine provided important, nutritious forage to elk, mule deer, and sheep in our study, we do not recommend seeding ranges grazed by cattle with spurred lupine or other lupines known to have the potential to cause crooked-calf disease. Rather, we point to the fact that this species readily inhabits aspen and sagebrush communities on stable and disturbed sites and risk of poisoning livestock warrants careful consideration in management plans.

\section{ACKNOWLEDGMENTS}

N. J. Bieker, J. S. Lewis, L. K. Peterson, C. S. Rudeen, and K. M. Smolski were invaluable field assistants. C. J. Williams provided statistical advice. B. B. Davitt, Wildlife Habitat and Nutrition Laboratory, Washington State University, Pullman, Washington, conducted microhistological fecal analysis. We thank K. E. Panter and T. Wierenga, USDA-ARS Poisonous Plant Research Laboratory, Logan, Utah, for analysis and interpretation of lupine alkaloids. The authors wish to thank the associate editor, Carolyn Hull Sieg, and 2 anonymous reviewers for their insightful comments that markedly improved our manuscript.

\section{LITERATURE CITED}

Abrams, P. 1980. Some comments on measuring niche overlap. Ecology 61: $44-49$.

Aebischer, N. J., P. A. Robertson, and R. E. Kenward. 1993. Compositional analysis of habitat use from animal radio-tracking data. Ecology 74:1313-1325.

AITCHISON, J. 1986. The statistical analysis of compositional data. London, England: Chapman and Hall. 416 p.

Altmann, J. 1974. Observational study of behavior: sampling methods. Behaviour 49:227-265.

Austin, D. D., And P. J. URness. 1985. Values of four communities for mule deer on ranges with limited summer habitat. Journal of Range Management 38:167-171.

BECK, J. L. 2003. Elk summer range habitat, nutritional ecology, and carrying capacity in the Jarbidge Mountains, Nevada [dissertation]. Moscow, ID: University of Idaho. $172 \mathrm{p}$.

Beck, J. L., J. T. Flinders, D. R. Nelson, C. L. Clyde, H. D. Smith, and P. J. Hardin. 1996. Elk and domestic sheep interactions in a north-central Utah aspen ecosystem. Ogden, UT: USDA Forest Service. Research Paper INT-RP-491. Available from: USDA Forest Service, USDA Forest Service Intermountain Research Station, Ogden, UT. 114 p.

Bonham, C. D. 1989. Measurements for terrestrial vegetation. New York, NY: John Wiley and Sons. $338 \mathrm{p}$.

Bugalho, M. N., and J. A. Milne. 2002. The composition of the diet of red deer (Cervus elaphus) in a Mediterranean environment: a case of summer nutritional constraint? Forest Ecology and Management 181:23-29.

Bureau of Land Management. 1996. Sampling vegetation attributes: Interagency technical reference. Denver, CO: Bureau of Land Management National Applied Resource Sciences Center, BLM/RS/ST-96/002+1730.

Cheeke, P. R. 1998. Natural toxicants in feeds, forages, and poisonous plants. 2nd ed. Danville, IL: Interstate Publishers Incorporated. $479 \mathrm{p}$.

Cole, G. F. 1958. Big game-livestock competition on Montana's mountain rangelands. Montana Wildlife (Apr):24-30.

Collins, W. B., AND P. J. URness. 1983. Feeding behavior and habitat selection of mule deer and elk on northern Utah summer range. Journal of Wildlife Management 47:646-683.

Cook, J. G. 2002. Nutrition and food. In: D. E. Toweill and J. W. Thomas [eds.]. North American elk: Ecology and management. Washington, DC: Smithsonian Institution Press. p 259-349.

DaviTT, B. B. 1979. Elk summer diet composition and quality on the Colockum Multiple Use Research Unit, central Washington [thesis]. Pullman, WA: Washington State University. $127 \mathrm{p}$.

DeByLE, N. V. 1985. Animal impacts. In: N. V. DeByle and R. P. Winokur, Jr. [eds.]. Aspen: Ecology and management in the western United States. Fort Collins, C0: USDA Forest Service, General Technical Report RM-119. p 115-123.

EluIson, L. 1954. Subalpine vegetation of the Wasatch Plateau, Utah. Ecological Monographs 24:89-184. 
Fowler, J., L. Cohen, and P. Jarvis. 1998. Practical statistics for field biology. 2nd ed. Chichester, West Sussex, England: John Wiley and Sons, Limited. 259 p.

Gardner, D. R., AND K. E. Panter. 1993. Comparison of blood plasma alkaloid levels in cattle, sheep, and goats fed Lupinus caudatus. Journal of Natural Toxins 2:1-11.

Gardner, D. R., And K. E. Panter. 1994. Ammodendrine and related piperidine alkaloid levels in the blood plasma of cattle, sheep, and goats fed Lupinus formosus. Journal of Natural Toxins 3:107-116.

Gogan, P. J. P., And R. H. BarRett. 1995. Elk and deer diets in a coastal prairiescrub mosaic, California. Journal of Range Management 48:327-335.

GruelL, G. E. 1998. Northern Elko County: the way it was. Northeastern Nevada Historical Society Quarterly 98-4:105-126.

Hanley, T. A. 1982. The nutritional basis for food selection by ungulates. Journal of Range Management 35:146-151.

Hanley, T. A., and K. A. Hanley. 1982. Food resource partitioning by sympatric ungulates on Great Basin rangeland. Journal of Range Management 35: $152-158$.

Hobbs, N. T., D. L. Baker, G. D. Bear, and D. C. Bowden. 1996a. Ungulate grazing in sagebrush grassland: mechanisms of resource competition. Ecological Applications 6:200-217.

Hobbs, N. T., D. L. Baker, G. D. Bear, and D. C. Bowden. 1996b. Ungulate grazing in sagebrush grassland: effects of resource competition on secondary production. Ecological Applications 6:218-227.

Hofmann, R. R. 1989. Evolutionary steps of ecophysiological adaptation and diversification of ruminants: a comparative view of their digestive system. Oecologia 78:443-457.

HoleCHEK, J. L. 1980. Concepts concerning forage allocation to livestock and big game. Rangelands 2:158-159.

Holechek, J. L., and R. Valdez. 1985. Magnification and shrub stemmy material influences on fecal analysis accuracy. Journal of Range Management 38: 350-352.

IRwin, L. L., And J. M. Peek. 1983. Elk, Cervus elaphus, foraging related to forest management and succession in Idaho. Canadian Field Naturalist 97: 443-447.

IvLEv, J. S. 1961. Experimental ecology of the feeding fishes. New Haven, CT: Yale University Press. 302 p.

Jenks, J. A., D. M. Leslie, JR., R. L. Lochmiller, M. A. Melchiors, and W. D. Warde. 1989. Effect of compositing samples on analysis of fecal nitrogen. Journal of Wildlife Management 53:213-215.

JoHnson, D. E. 1998. Applied multivariate methods for data analysts. Pacific Grove, CA: Duxbury Press, Brooks/Cole Publishing Company. 567 p.

KeELER, R. F. 1976. Lupin alkaloids from teratogenic and nonteratogenic lupins. III. Identification of anagyrine as the probable teratogen by feeding trials. Journal of Toxicology and Environmental Health 1:887-898.

KIE, J. G., And B. B. Boroski. 1996. Cattle distribution, habitats, and diets in the Sierra Nevada of California. Journal of Range Management 49:482-488.

Kingsbury, J. M. 1964. Poisonous plants of the United States and Canada. Englewood Cliffs, NJ: Prentice-Hall Inc. $626 \mathrm{p}$.

KorfHAge, R. C. 1974. Summer food habits of elk in the Blue Mountains of northeastern Oregon based on fecal analysis [thesis]. Pullman, WA: Washington State University. $117 \mathrm{p}$.

LEWIS, M. E. 1975. Plant communities of the Jarbidge Mountain complex, Humboldt National Forest. Ogden, UT: USDA Forest Service. Report to Intermountain Region. $22 \mathrm{p}$.

Litvaitis, J. A., K. Titus, and E. M. Anderson. 1994. Measuring vertebrate use of terrestrial habitats and foods. In: T. A. Bookhout [ed.]. Research and management techniques for wildlife and habitats. 5th ed. Bethesda, MD: The Wildlife Society. p 254-274.

Lopez-Ortiz, S., K. E. Panter, J. A. Pfister, and K. L. Launchbaugh. 2004. The effect of body condition on disposition of alkaloids from silvery lupine (Lupinus argenteus Pursh) in sheep. Journal of Animal Science 82:27982805.

MILleR, W. 2002. Elk interactions with other ungulates. In: D. E. Toweill and J. W. Thomas [eds.]. North American elk: Ecology and management. 2nd ed. Washington, DC: Smithsonian Institution Press. p 435-447.

Mower, K. J., AND H. D. SMith. 1989. Diet similarity between elk and deer in Utah. Great Basin Naturalist 49:552-555.

MuegGleR, W. F. 1988. Aspen community types in the Intermountain Region. Ogden, UT: USDA Forest Service. General Technical Report INT-250. 135 p.

Nevada Division of Wildiffe. 1997. Nevada elk species management plan. Reno, NV: Nevada Division of Wildlife. $66 \mathrm{p}$.

NevadA Division of Wildiffe. 2000. Sub-plan for elk management in the Jarbidge Mountains, Nevada. Reno, NV: Nevada Division of Wildlife. 4 p.

OeHLERT, G. W. 2000. A first course in the design and analysis of experiments. New York, NY: W.H. Freeman and Co. 659 p.

OLSEN, F. W., And R. M. Hansen. 1977. Food relations of wild free-roaming horses to livestock and big game, Red Desert, Wyoming. Journal of Range Management 30:17-20.

Pederson, J. C., and K. T. Harper. 1978. Factors influencing productivity of two mule herds in Utah. Journal of Range Management 31:105-110.

Pulliam, D. E., JR., and J. R. Nelson. 1979. Determination of digestibility coefficients for quantification of fecal analysis with elk. In: M. S. Boyce and L. D. Hayden-Wing [eds.]. North American elk: Ecology, behavior, and management. Laramie, WY: University of Wyoming. p 240-246.

Ralphs, M. H., and J. A. Pfister. 1992. Cattle diets in tall forb communities on mountain rangelands. Journal of Range Management 45:534-537.

SAS InStITUTE. 2001. SAS/STAT User's Guide, Release 8.2. Cary, NC: SAS Institute, Inc.

SCHOener, T. W. 1970. Nonsynchronous spatial overlap of lizards in patchy habitats. Ecology 51:408-418.

Smitman, G. E. 1980. An examination of laboratory techniques for quantification of elk fecal analysis [thesis]. Pullman, WA: Washington State University. $58 \mathrm{p}$.

Stephenson, T. E., J. L. Holechek, and C. B. Kuykendall. 1985. Drought effect on pronghorn and other ungulate diets. Journal of Wildlife Management 49: 146-151.

TISDAle, E. W. 1994. Mountain big sagebrush SRM 402. In: T. N. Shiflet [ed.]. Rangeland cover types of the United States. Denver, CO: The Society for Range Management. p 41-42.

Tueller, P. T., And L. A. Monroe. 1975. Management guidelines for selected deer habitats in Nevada. Reno, NV: University of Nevada Agricultural Experiment Station. Publication R 104. 185 p.

USDA Forest SERVICE. 1981. Environmental assessment for the release of elk into the Jarbidge Mountains, Elko County, Nevada. Elko, NV: USDA Forest Service, Humboldt National Forest. $25 \mathrm{p}$.

usda natural Resources Conservation Service. 2004. The Plants database, version 3.5. Baton Rouge, LA: National Plant Data Center. Available at: http:// plants.usda.gov. Accessed 8 October 2004.

Wisdom, M. J., AND J. W. Thomas. 1996. Elk. In: P. R. Krausman [ed.]. Rangeland wildlife. Denver, C0: The Society for Range Management. p 157-181. 